\title{
Nutritional, haematinic and biosafety evaluation of Ipomoea batatas (L.) Lam. (Solanales: Convolvulaceae) leaf extract on albino rats
}

\author{
Benjamin 0. Gabriel and MacDonald Idu*
}

Phytomedicine Unit. Department of Plant Biology and Biotechnology. PMB 1154. Benin. Edo State. Nigeria. *Email: mcdonald@uniben.edu.

\begin{abstract}
This study evaluates the nutritional, Haematinic and biosafety of Ipomoea batatas (L.) Lam. (Solanales: Convolvulaceae) aqueous leaf extract on albino rats. Proximate and mineral compositions were determined using standard methods. Haematinic activity of the plant was done using graded doses; 125,250 , and $500 \mathrm{mg} / \mathrm{kg}$ and $40 \mathrm{mg} / \mathrm{kg}$ phenyl hydrazine hydrochloride to induce anaemia. A modified method was used for acute and sub-acute toxicological evaluations. Results from the study showed that aqueous extracts of I. batatas had significant increase in RBC, HCT, Hgb, MCV, MCH and MCHC at $7.19 \pm 0.45,46.13 \pm 0.08,13.43 \pm 0.27,82.40 \pm 0.92,24.15 \pm 1.24$ and $37.78 \pm 0.20$, respectively, when compared with the control group. Acute study showed no pathological behaviour with absent mortality. Sub-acute study of the spleen, heart, liver and kidney showed a mild activation of local immune system. The extracts recorded $89.14 \%$ scavenging property compared with $94.3 \%$ ascobate in antioxidant study. Proximate analysis had $31.56 \%$ of moisture content, $16.25 \%$ of protein, $7.64 \%$ of ash, $0.37 \%$ of crude fibre, $0.19 \%$ of fat and $43.99 \%$ of carbohydrate. Investigation of calcium, magnesium, Iron, potassium, phosphorus, sodium and zinc were 28.03, 339.61, 15.87, 4.61, $35.90,4.21$ and $0.08 \mathrm{mg} / \mathrm{kg}$ others were not detected. This may be due to stimulating mechanism of Myelo-Erythroid cell ratio in bone marrow or antioxidant effect. Result thus validates ethnobotanical uses of $I$. batatas for the treatment of anaemia.
\end{abstract}

Keywords: Sweetpotato; Anaemia; Bone marrow; Peripheral blood smear; Phenylhydrazine hydrochloride.
Received

February 16, 2019

Available on line:

July 13, 2019

Accepted

July 12, 2019

Released

Augusto 31, 2019

Full Text Article

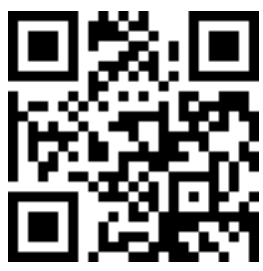

ORCID

(1) 0000-0002-2513-385X

Benjamin 0. Gabriel

(D) 0000-0002-5082-1988

MacDonald Idu

\section{Introduction}

Currently, complimentary/alternative use of medicines, especially the consumption of phytochemicals has rapidly increased universally. Herbal medicines have less or no damaging effect than conventional drugs. They improve patient tolerance on prolong use (Kaliora et al., 2006). Ipomea batatas (L.) Lam. (Solanales: Convolvulaceae) is a native to Central and Southern America, the un-recent known plants to human. Sweet potato is herbaceous perennial vegetable with white and purple flowers and long nutritious storage roots (Antia 
et al., 2006; Ozaki et al., 2010). Recently, numbers of reports showed that, I. batatas phytochemicals exhibit antioxidative or radical-scavenging effect with health-promoting property in humans (Konczak-Islam et al., 2003; Suda et al., 2003; Rabah et al., 2004; Dini et al., 2009). The plant supports correct heart functions (Noda and Horiuchi, 2008). I. batatas has a broad Ethnomedicinal function which includes; anti-anemic, anti-inflammatory, antifertility, anti-carcinogenesis, antimutagenity, anti-diabetes, antihemorrhagic, and promote stable blood sugar level (Bratosin et al., 1998; Lippi et al., 2012).

Extrinsic anemia arises as hemolytic anemia in blood vessels known as intravascular haemolysis or other body parts called extra-vascular. The potential cause varies from safe anemia to life-threatening anemia. Usually, hemolytic anemia can either be classified as merited or acquired (Telford et al., 2003). Peripheral blood films stained test using Wright's stain present vital diagnosis understanding of anemia with various diseases associated to leukocytes and platelets (Lessin et al., 2006; Komolafe and Awoniyi, 2013).

The objective of this study is to evaluate the nutritional, haematinic and toxicological profile of $I$. batatas extracts.

\section{Materials and methods}

\section{Collection of plant material}

Sweet potatoes leaves (I. batatas) were gotten from Akure, Ondo State, Nigeria. It was identified and authenticated by Dr. O. Timothy in the Department of Plant Biology and Biotechnology, University of Benin, Benin City Edo State, Nigeria.

\section{Preparation of plant material}

The leaves were rinsed and air dried for 3 days, afterwards oven dried at $40{ }^{\circ} \mathrm{C}$ for few hours. The crunchy leaves were pulverized into powder with electrical grinder and extracted using aqueous solvent. It was stored in an airtight container for further application.

\section{activities \\ Determination of antioxidant \\ Free radical scavenging activity} of $I$. batatas leaves extract against 1, 1Diphenyl-2-picrylhydrazyl radical (Sigma Aldrich) was evaluated by $517 \mathrm{~nm}$ UV spectrophotometer. The radical scavenging property was measured using slight modified method described by Leong and Shui (2002):

$\%$ inhibition $=\left(A_{a}-A_{a} / A_{b}\right) \times 100$

Where $A_{b}$ is absorption for the blank sample and Aa the absorption for the extract

\section{Nutritional evaluation \\ Proximate analysis/compo-} sition. The proximate analysis (gross chemical composition) was determined by the recommended method of AOAC (2005). This includes:

Moisture content determination. $2 \mathrm{~g}$ of the dry sample was placed in a crucible of $31.990 \mathrm{~g}$, the crucible then was put into the oven for $3 \mathrm{~h}$ at $105^{\circ} \mathrm{C}$ until a constant weight was attained. The crucible was transferred to a dessicator to cool and the weight was noted to $33.786 \mathrm{~g}$. The percentage moisture constituent was calculated as:

$$
\% \mathrm{MC}=\frac{\mathrm{WLS}}{\mathrm{WOS}} \times 1,000
$$

Where:

$\mathrm{MC}=$ Moisture content

WLS = weight loss by sample

WOS = weight of original sample

$$
\% \mathrm{DM}=100-\% \mathrm{MC}
$$

Where:

DM $=$ Dry matter

$\mathrm{MC}=$ Moisture content 
Ash content determination. $2 \mathrm{~g}$ weight of the dry sample was introduced in a crucible of $31.981 \mathrm{~g}$. The crucible was then placed in the muffle furnace and was set at $550^{\circ} \mathrm{C}$ for three hours for complete ashing. The crucible was brought out from the furnace after the designated time and was taken to the dessicator to cool, after which the weight was noted to be $32.355 \mathrm{~g}$. The ash constituent was calculated as:

$$
\% \mathrm{AC}=\frac{\mathrm{WA}}{\mathrm{WS}} \times 100
$$

Where:

$\mathrm{AC}=$ Ash content

WA $=$ Weight of ash

WS $=$ Weight of sample

$$
\% \mathrm{OM}=100-\% \mathrm{AC}
$$

Where:

$\mathrm{OM}=$ Organic Matter

$\mathrm{AC}=$ Ash content

Crude oil determination. $1 \mathrm{~g}$ of the dry sample was conveyed into filter paper of $1.550 \mathrm{~g}$. The filter paper was then wrapped and placed in the extraction chamber of the soxhlet extractor. The extraction flask was two quarter filled with petroleum ether (organic solvent) for the extraction of oil from the sample. The extraction continued with the organic solvent extracting the oil from the sample by boiling gently and leaving it to siphon over several hours until the solvent in the chamber becomes clear. The filter paper was collected and placed in the oven at $105^{\circ} \mathrm{C}$ for one hour. The filter paper was then cooled in the dessicator and weighed to be 2.468g. The percentage fat was then calculated as:

$$
\frac{\text { Difference in weight }}{\text { Original weight }} \times 100
$$

Crude fibre determination. $1 \mathrm{~g}$ of the defatted sample was transferred into $260 \mathrm{~mL}$ conical flask. For acid digestion, $100 \mathrm{~mL}$ of boiling $1.25 \% \mathrm{H}_{2} \mathrm{SO}_{4}$ was poured and made to boil within an minute, and then it was boiled gently for 30 min maintaining a constant volume with the help of the wash bottle. The mixture was then filtered through a poplin cloth by suction using Buchner funnel, the poplin cloth was then rinsed thoroughly with hot distilled water and the residue was transferred into another flask with spatula for alkaline. $100 \mathrm{~mL}$ of boiling $1.25 \% \mathrm{NaOH}$ was added, and brought to boiling in $1 \mathrm{~min}$, it was left to boil gently for $30 \mathrm{~min}$. The process of filtering through a poplin cloth was repeated. The residue was thoroughly savaged from the poplin cloth with the help of spatula and the remaining residue was rinsed off from the poplin cloth into the crucible with ethanol. The crucible was then dried with sample in an oven at $105{ }^{\circ} \mathrm{C}$ for one hour and was transferred into a dessicator to cool before the weight was taken to be $30.892 \mathrm{~g}$. The crucible was then transferred with the sample into muffle furnace at $300{ }^{\circ} \mathrm{C}$ for two hours and then into the dessicator to cool. The percentage crude fibre was calculated as:

$$
\% \mathrm{CF}=\frac{\mathrm{WD}-\mathrm{WAS}}{\mathrm{WS}} \times 100
$$

Where:

$\mathrm{CF}=$ crude fibre

$\mathrm{WD}=$ weight of digest

WAS = weight of ash sample

WS = weight of sample

\section{Crude protein determination}

Crude protein determination of the sample was done the kjeldahl method with a little modification. $1 \mathrm{~g}$ of the dry sample was taken into the digestion flask with $5 \mathrm{~g}$ of the digestion mixture added to it. $25 \mathrm{~mol}$ of concentrated $\mathrm{H}_{2} \mathrm{SO}_{4}$ was added to the flask swirled in other to mix the content thoroughly before it was placed on the heating mantle for the 
digestion process to commence, so that a clear mixture was achieved. The digest was allowed to chilled, poured into a 100 mol volumetric flask to the required mark before it was then filtered. Distillation of the digest was perform with $100 \mathrm{~mL}$ of digest being introduced into a distillation flask, $30 \mathrm{~mol}$ of distilled water and $10 \mathrm{~mol}$ of $40 \% \mathrm{NaOH}$ was gradually added through the process. The distillation process was completed after 20 min with ammonia $\left(\mathrm{NH}_{3}\right)$ produce as ammonium hydroxide $\left(\mathrm{NH}_{4} \mathrm{OH}\right)$, in a conical flask with $5 \mathrm{~mol}$ of boric acid mixed indicator. The distillate was titrated against $0.1 \mathrm{M}$ HCL standard solution till pink colour was observed. The percentage crude protein of the sample was calculated as:
$\% \mathrm{CP}=\% \mathrm{~N} \times$ Crude factor

Where:

$$
\% \mathrm{~N}=\frac{\mathrm{S} \times 0.014 \times \mathrm{D}}{\mathrm{Wt} \times \mathrm{V}} \times 100
$$

$\mathrm{S}=$ Sample titration reading $(100 \mathrm{~mL})$

$\mathrm{D}=$ Dilution of sample after digest $\mathrm{mL})$ nitrogen

$\mathrm{V}=$ Volume taken for distillation (10

$0.014=$ Milli-equivalent weight of

Wt $=$ Weight of sample used

Crude factor $=6.25$

Nitrogen Free Extract. The NFE was obtained by subtracting the amounts of all five fractions above from 100\%. Thus NFE is determined as follows:

$$
\mathrm{NFE}=100-(\% \text { water }+\% \text { ash }+\% \text { crude protein }+\% \text { crude fibre }+\% \text { crude oil })
$$

\section{Determination of mineral elements composition}

Weighed $5 \mathrm{~g}$ of the leave powdered was ashed at $550^{\circ} \mathrm{C}$ in a muffle furnace for $5 \mathrm{~h}$ and the residue liquefied in $100 \mathrm{ml}$ deionised water. Standard solutions of the minerals were prepared and used to calibrate the atomic absorption spectrophotometer (AAS) (model 969 AA, Unicamseries) using acetylene-air flame at certain wavelengths. Aliquots of the ash solutions were inserted into AAS and from the standard curve the various concentrations were obtained.

\section{Experimental animals}

Fifty four healthy Wistar albino rat weighing 180-250 g. The animals were obtained in the Animal and Environmental Biology, University of Benin animal house. They were housed in a well-ventilated woody cages in normal laboratory state $(12 \mathrm{~h}$ light/dark cycle: $23^{\circ} \mathrm{C} \pm 2{ }^{\circ} \mathrm{C}$ ) and fed with standard diet. Food and water were given ad libitum to the animals. They were handled in accordance to standard protocols of National Institute of Health USA: Public Health Service policy on humane care and use of Laboratory Animals (2002).

\section{Experimental protocol}

Phenylhydrazine hydrochloride induced anaemia was grouped as follows:

Six groups, of 9 animals per group received the following treatment schedule.

Group A: Received distilled water (0.5 ml/kg p.o.) alone.

Group B: Received ferrous (iii) hydroxide poly-maltose (5 mg/kg p.o.).

Group C: Received phenyl hydrazine hydrochloride (40 mg/kg p.o.) alone.

Group D: Received aqueous extract of I. batatas (125 mg/kg p.o.).

Group E: Received aqueous extract of I. batatas (250 mg/kg p.o.).

Group F: Received aqueous extract of I. batatas (500 mg/kg p.o.). 
Animals were fasted overnight before administration of phenyl hydrazine hydrochloride according to body weight; they were post-treated for 14 consecutive days. Three rats were sacrificed across the groups for 0,7 and 14 days. The necessary sample were then analyzed.

\section{Bone marrow preparation}

Bone marrows were decalcified into slides and interpreted with pictures.

\section{Acute toxicity study}

Across the groups, the animals were observed for 4 and $24 \mathrm{~h}$ for every behavioral changes such as hypersensitivity, sedation, hyperrespiration, hyperactivity, itching, salivation, diarrhea, convulsion, coma and dead after the administration of the extract at respective doses $(125 \mathrm{mg} / \mathrm{kg}$, $250 \mathrm{mg} / \mathrm{kg}$ and $500 \mathrm{mg} / \mathrm{kg}$ ), and distilled water. Lethality or Mortality was calculated after $24 \mathrm{~h}$ and the lethal dose $\left(\mathrm{LD}_{50}\right)$ was determined. All animals were observed for 14 days for delayed mortality.

\section{Hematology assays}

Automated sysmex

hematology analyzer (Sysmex Corporation, Kobe, Japan) was used for the determination of red blood cells (RBC), hemoglobin (HGB), haematocrit (HCT), mean corpuscular volume (MCV), mean corpuscular hemoglobin (MCH), mean corpuscular hemoglobin concentration (MCHC), red cell distribution width (RCDW), white blood cell (WBC), monocytes (MO), lymphocytes (LY), platelets (PLT). Platelets crit (PCT), platelet density width (PDW), mean platelet volume (MPV) and granulocytes (GR).

\section{Histopathological study}

Organs such as; Liver, Kidney, Heart, Spleen which were fixed in 10\% (vol/vol) formaldehyde, cleaned up in xylene and, embedded in paraffin wax (melting point at 56\%) for organ preservation. Tissue sections were prepared according to the method of Drury and Wallinton (2003) and stained with eosin/hematoxylin. Photomicrographs were taken at $\times 400$ magnifications using digital camera.

\section{Statistical analysis}

Data were presented as (SEM) of the respective replicates. (ANOVA) was used to compare means of different sample significance; Duncan Multiply Range test shows the source of significance (Post hoc test). SPSS 21.0 computer software package. Microsoft Excel 2013 version was used for analysis. $\mathrm{P} \leq 0.05$ (95\% confidence interval) was considered significant, while $\mathrm{P} \leq 0.01$ (99\% confidence interval) was considered as highly significant.

\section{Results}

\section{Antioxidant activity \\ DPPH scavenging activity of} I. batatas leaf extracts. The results of the total Antioxidant activity of aqueous extract of $I$. batatas indicated in Figure 1. Aqueous extract was observed to possess the highest radical scavenging potential with inhibition of $77.97 \%$ at $80 \mu \mathrm{g} / \mathrm{mL}$ and $89.14 \%$ at $100 \mu \mathrm{g} / \mathrm{mL}$, when compared with standard (ascorbic acid) $92.91 \%$ at $80 \mu \mathrm{g} / \mathrm{mL}$ and $94.3 \%$ at $100 \mu \mathrm{g} / \mathrm{mL}$. 


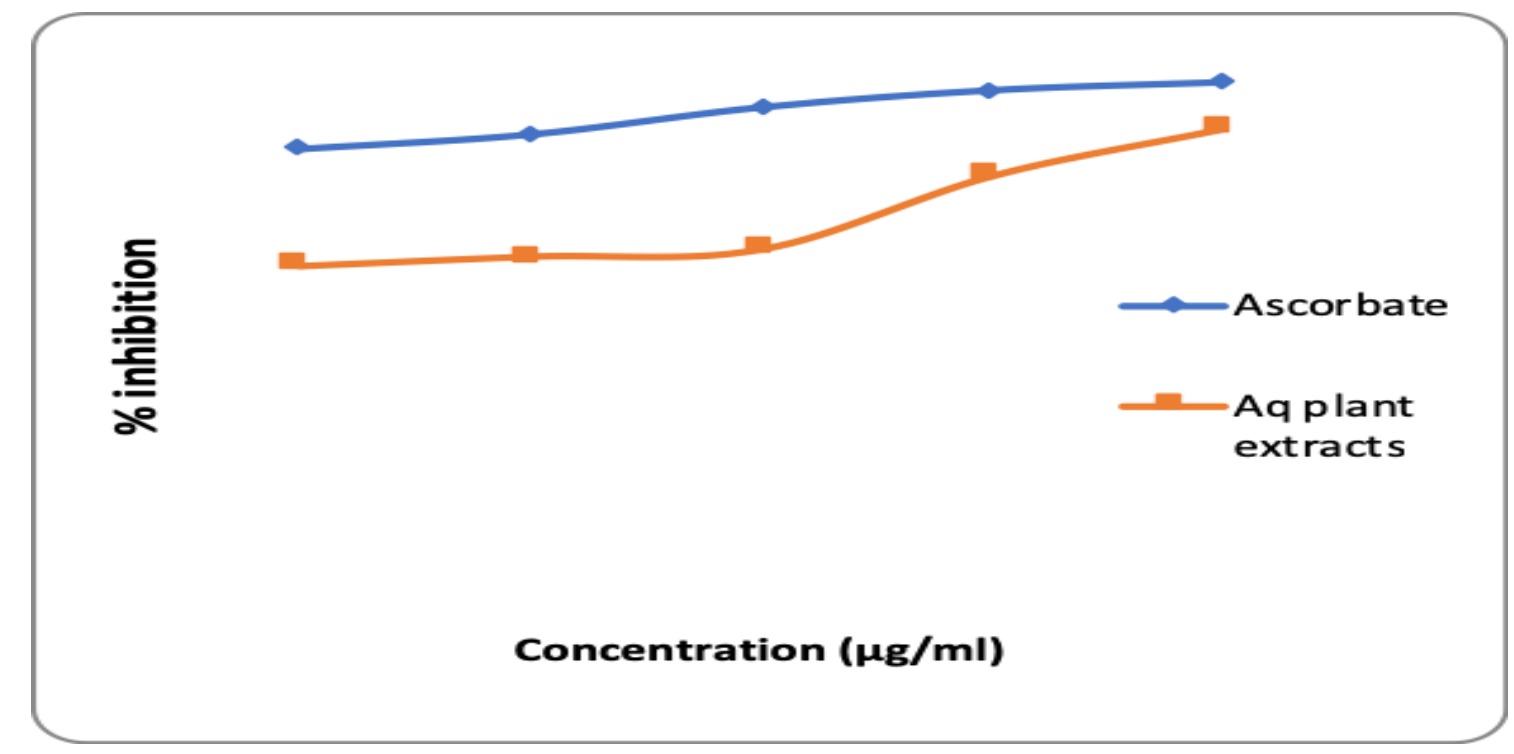

Figure 1. DPPH scavenging activities of crude aqueous extracts of $I$. batatas leave ascorbic acid.

Nutritional evaluation value below indicated that I. batatas contain for I. batatas aqueous extracts moisture content, protein, ash content, The percentage composition on dry weight level as shown in the Figure 2, crude fibre, fat and carbohydrate at a moderate amount.

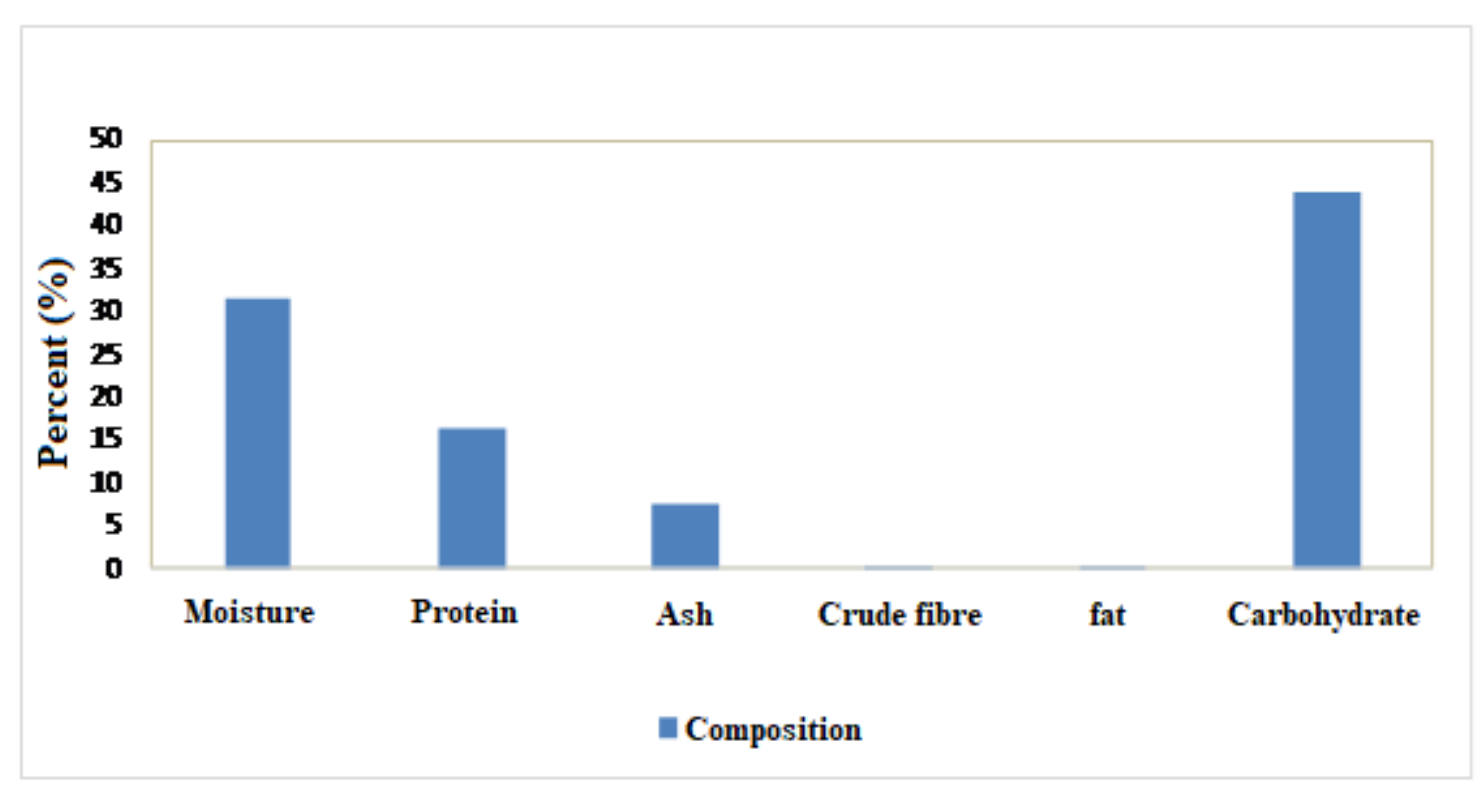

Figure 2. Proximate composition of I. batatas aqueous leave extract. 
Mineral element composition on aqueous extract of $I$. batatas

Figure 3 revealed that the leave extract of $I$. batatas has a reasonable percentage of magnesium, phosphorus, calcium and iron with a fair percentage of potassium, and sodium, and a very low percentage of zinc.

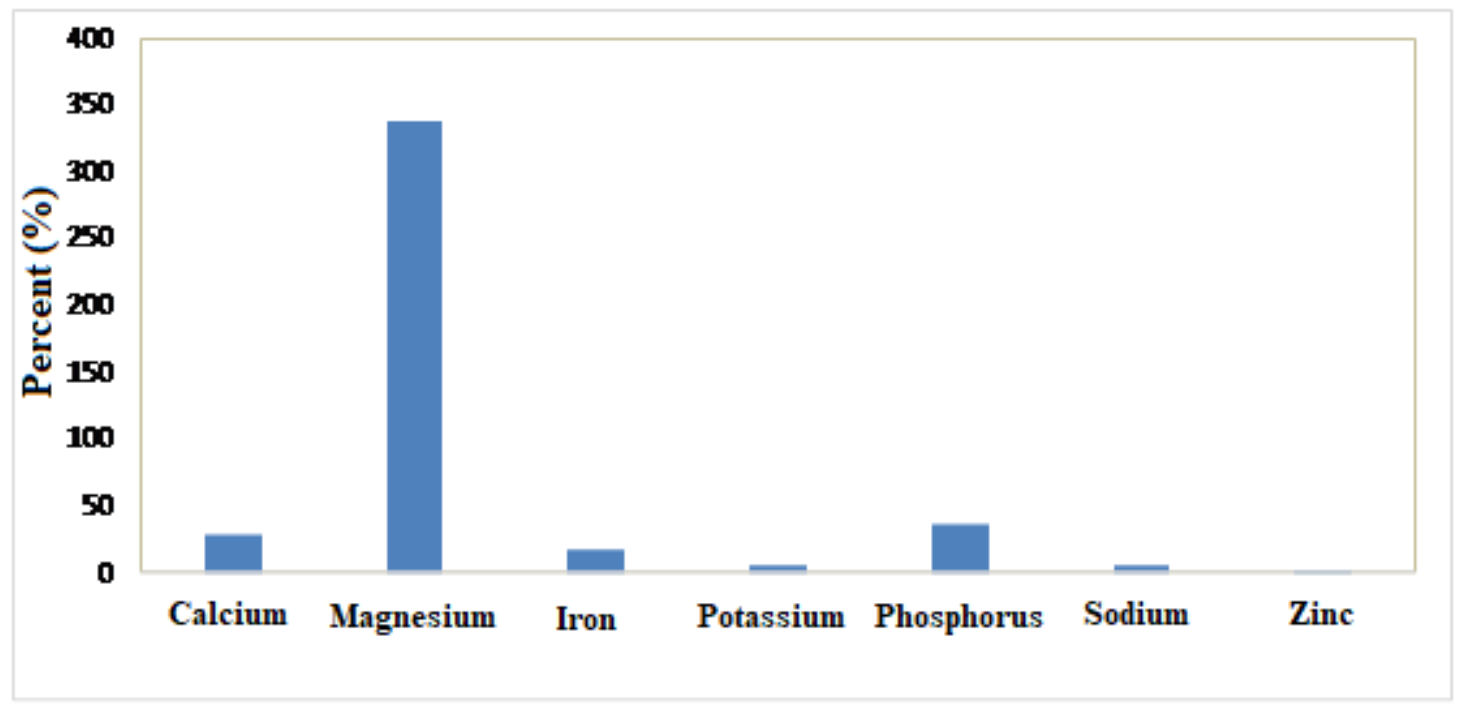

Figure 3. Elemental compositions of I. batatas leaf extract.

\section{Hematology analysis}

Table 1 shows significant decrease in Red blood cell count across $40 \mathrm{mg} / \mathrm{kg}$ Phenylhydrazine, $10 \mathrm{mg} / \mathrm{kg}$ ferrous (iii) - hydroxide and treated groups in day 1 of the experiment with subsequent onset of action by an increased in day 7 and 14 of the treated group with aqueous leaves extract of I. batatas.

Table 1. Effect of aqueous leaves extract of $I$. batatas on red blood cell count (RBC) $\mathrm{x} 10^{6} / \mu \mathrm{l}$ in phenyl hydrazine-induced anemia.

\begin{tabular}{lcccc}
\hline Treatment & $\begin{array}{c}\text { Doses } \\
(\mathbf{m g} / \mathbf{k g})\end{array}$ & Day 1 & Day 7 & Day 14 \\
\hline Phenylhydrazine & 40 & $3.77 \pm 0.39$ & $3.68 \pm 0.33$ & $4.33 \pm 0.19$ \\
Ferrous (iii) - Hydroxide & 10 & $4.96 \pm 0.50^{\mathrm{a}}$ & $5.01 \pm 0.48^{\mathbf{a}}$ & $6.19 \pm 0.47$ \\
Control & DW & $5.01 \pm 0.28^{\mathrm{a}}$ & $5.41 \pm 017^{\mathbf{b}}$ & $7.96 \pm 1.16^{\mathbf{b}}$ \\
Ipomoea batatas & 125 & $5.05 \pm 0.06^{\mathrm{a}}$ & $5.02 \pm 0.03^{\mathrm{a}}$ & $6.20 \pm 0.69$ \\
Ipomoea batatas & 250 & $5.09 \pm 0.05^{\mathrm{a}}$ & $5.12 \pm 0.04^{\mathbf{b}}$ & $6.42 \pm 0.67$ \\
Ipomoea batatas & 500 & $5.13 \pm 0.06^{\mathrm{a}}$ & $5.17 \pm 0.06^{\mathbf{b}}$ & $7.19 \pm 0.45^{\mathbf{a}}$ \\
\hline
\end{tabular}

Values are mean \pm SEM with $\mathrm{p}$-value $<0.05$. DW $=$ Distilled water. 
Table 2 shows significant decrease in Packed Cell Volume across $40 \mathrm{mg} / \mathrm{kg}$ Phenylhydrazine, $10 \mathrm{mg} / \mathrm{kg}$ ferrous (iii) - hydroxide and treated groups by day 1 of the experiment with subsequent increase in day 7 and 14 of the experiment after treatment with aqueous leaves extract of $I$. batatas.

Table 2. Effect of I. batatas aqueous leaves extract on Haematocrit (HCT)\% in phenyl hydrazineinduced anemia.

\begin{tabular}{lcccc}
\hline Treatment & Doses $\mathbf{~ m g / k g ) ~}$ & Day 1 & Day 7 & Day 14 \\
\hline Phenylhydrazine & 40 & $36.39 \pm 1.83$ & $35.42 \pm 1.80$ & $35.73 \pm 2.37$ \\
Ferrous (iii) - Hydroxide & 10 & $39.04 \pm 0.58$ & $41.01 \pm 0.61^{\mathbf{a}}$ & $45.35 \pm 2.69 \mathbf{a}$ \\
Control & DW & $41.15 \pm 0.46^{\mathbf{b}}$ & $42.36 \pm 0.33^{\mathbf{b}}$ & $53.83 \pm 1.16^{\mathbf{c}}$ \\
Ipomoea batatas & 125 & $42.29 \pm 0.37^{\mathbf{b}}$ & $42.71 \pm 0.89^{\mathbf{b}}$ & $46.13 \pm 0.08^{\mathbf{b}}$ \\
Ipomoea batatas & 250 & $41.75 \pm 0.38^{\mathbf{b}}$ & $42.60 \pm 0.94^{\mathbf{b}}$ & $45.58 \pm 2.55^{\mathbf{a}}$ \\
Ipomoea batatas & 500 & $40.74 \pm 0.37^{\mathbf{a}}$ & $41.74 \pm 1.17^{\mathbf{b}}$ & $44.10 \pm 1.10^{\mathbf{a}}$ \\
\hline
\end{tabular}

Values are mean \pm SEM with $p$-value $<0.05$. DW $=$ Distilled water.

Table 3 shows significant decrease in hemoglobin across across $40 \mathrm{mg} / \mathrm{kg}$ Phenylhydrazine, $10 \mathrm{mg} / \mathrm{kg}$ ferrous (iii) - hydroxide and treated groups by day 1 of the experiment with subsequent increase in day 14 of the experiment after treatment with aqueous leaves extract of I. batatas.

Table 3. Effect of $I$. batatas aqueous leaves extract on Hemoglobin (Hg) g/dL in phenyl hydrazineinduced anemia.

\begin{tabular}{lcccc}
\hline Treatment & $\begin{array}{c}\text { Doses } \\
\text { (mg/kg) }\end{array}$ & Day 1 & Day 7 & Day 14 \\
\hline Phenylhydrazine & 40 & $11.49 \pm 0.35$ & $12.19 . \pm 0.25$ & $12.18 \pm 0.60$ \\
Ferrous (iii) - Hydroxide & 10 & $12.15 \pm 0.14$ & $13.23 \pm 0.35^{\mathbf{a}}$ & $14.35 \pm 1.36$ \\
Control & DW & $13.30 \pm 0.23^{\mathbf{c}}$ & $13.83 \pm 0.13^{\mathbf{b}}$ & $14.76 \pm 1.15$ \\
Ipomoea batatas & 125 & $12.72 \pm 0.20^{\mathbf{b}}$ & $13.43 \pm 0.27 \mathrm{a}$ & $14.40 \pm 0.92$ \\
Ipomoea batatas & 250 & $12.87 \pm 0.15^{\mathbf{b}}$ & $13.21 \pm 0.23^{\mathbf{a}}$ & $14.35 \pm 0.20$ \\
Ipomoea batatas & 500 & $12.14 \pm 0.07$ & $12.77 \pm 0.14$ & $13.95 \pm 0.55$ \\
\hline
\end{tabular}

Values are mean \pm SEM with $p$-value $<0.05$. DW $=$ Distilled water.

Table 4 shows significant decrease in Mean Corpuscular Volume across $40 \mathrm{mg} / \mathrm{kg}$ Phenylhydrazine, $10 \mathrm{mg} / \mathrm{kg}$ ferrous (iii) - hydroxide and treated groups in day 1 of the experiment with subsequent increase in 14 of the experiment after treatment with aqueous leaves extract of $I$. batatas. 
Table 4. Effect of $I$. batatas aqueous leaves extract on Mean Corpuscular Volume (MCV) fl in phenyl hydrazine-induced anemia.

\begin{tabular}{lcccc}
\hline Treatment & $\begin{array}{c}\text { Doses } \\
(\mathbf{m g} / \mathbf{k g})\end{array}$ & Day 1 & Day 7 & Day 14 \\
\hline Phenylhydrazine & 40 & $56.76 \pm 6.21$ & $57.96 . \pm 5.90$ & $67.16 \pm 2.40$ \\
Ferrous (iii) - Hydroxide & 10 & $67.18 \pm 3.19$ & $70.22 . \pm 0.41^{\mathbf{a}}$ & $74.10 \pm 1.39$ \\
Control & $\mathrm{DW}$ & $69.92 \pm 1.34^{\mathbf{a}}$ & $71.20 \pm 0.71^{\mathbf{b}}$ & $84.75 \pm 2.31^{\mathbf{c}}$ \\
Ipomoea batatas & 125 & $70.36 \pm 0.38^{\mathbf{a}}$ & $71.17 \pm 0.35^{\mathbf{b}}$ & $75.13 \pm 2.96$ \\
Ipomoea batatas & 250 & $69.48 \pm 0.62^{\mathbf{a}}$ & $70.40 \pm 0.45^{\mathbf{a}}$ & $82.40 \pm 0.92^{\mathbf{c}}$ \\
Ipomoea batatas & 500 & $71.00 \pm 0.26^{\mathbf{a}}$ & $71.14 \pm 0.27^{\mathbf{a}}$ & $76.10 \pm 0.64^{\mathbf{a}}$ \\
\hline
\end{tabular}

Values are mean \pm SEM with p-value $>0.05$. DW $=$ Distilled water.

Table 5 shows significant decrease in Mean Corpuscular Haemoglobin Concentration across $40 \mathrm{mg} / \mathrm{kg}$ Phenylhydrazine, $10 \mathrm{mg} / \mathrm{kg}$ ferrous (iii) hydroxide and treated groups in day 1 of the experiment with subsequent increase in day 14 of the experiment after treatment with aqueous leaves extract of I. batatas.

Table 5. Effect of $I$. batatas aqueous leaves extract on Mean Corpuscular Hemoglobin (MCH) pg in phenyl hydrazine- induced anemia.

\begin{tabular}{lcccc}
\hline Treatment & $\begin{array}{c}\text { Doses } \\
\text { (mg/kg) }\end{array}$ & Day 1 & Day 7 & Day 14 \\
\hline Phenylhydrazine & 40 & $16.58 \pm 0.70$ & $19.14 . \pm 0.63$ & $19.20 \pm 045$ \\
Ferrous (iii) - Hydroxide & 10 & $18.81 \pm 2.91$ & $21.94 . \pm 0.33^{\mathbf{b}}$ & $23.35 \pm 1.53$ \\
Control & $\mathrm{DW}$ & $22.33 \pm 0.45^{\mathbf{a}}$ & $22.85 \pm 0.52^{\mathbf{c}}$ & $25.83 \pm 2.89 \mathbf{a}$ \\
Ipomoea batatas & 125 & $21.76 \pm 0.42$ & $22.39 \pm 0.40^{\mathbf{b}}$ & $23.55 \pm 0.26$ \\
Ipomoea batatas & 250 & $22.04 \pm 0.58^{\mathbf{a}}$ & $22.43 \pm 0.46^{\mathbf{b}}$ & $24.15 \pm 1.24^{\mathbf{a}}$ \\
Ipomoea batatas & 500 & $21.30 \pm 0.45$ & $21.56 \pm 0.41^{\mathbf{a}}$ & $22.45 \pm 0.90$ \\
\hline
\end{tabular}

Values are mean \pm SEM with $p$-value $>0.05$. DW $=$ Distilled water.

Table 6 shows significant decrease in Mean Corpuscular Haemoglobin Concentration across $40 \mathrm{mg} / \mathrm{kg}$ Phenylhydrazine, $10 \mathrm{mg} / \mathrm{kg}$ ferrous (iii) - hydroxide and treated groups in day 1 of the experiment with subsequent increase in day 7 and 14 of the experiment after treatment with aqueous leaves extract of $I$. batatas. 
Table 6. Effect of $I$. batatas aqueous leaves extract on Mean Corpuscular Hemoglobin (MCHC) pg in phenyl hydrazine- induced anemia.

\begin{tabular}{lcccc}
\hline Treatment & $\begin{array}{c}\text { Doses } \\
(\mathbf{m g} / \mathbf{k g})\end{array}$ & Day 1 & Day 7 & Day 14 \\
\hline Phenylhydrazine & 40 & $27.35 \pm 1.50$ & $31.92 . \pm 0.89$ & $32.25 \pm 0.56$ \\
Ferrous (iii) - Hydroxide & 10 & $31.47 \pm 0.48^{\mathbf{b}}$ & $34.470 .71^{\mathbf{a}}$ & $34.81 \pm 0.99^{\mathbf{a}}$ \\
Control & $\mathrm{DW}$ & $32.84 \pm 0.65^{\mathbf{b}}$ & $36.74 \pm 0.60^{\mathbf{c}}$ & $37.09 \pm 0.31^{\mathbf{c}}$ \\
Ipomoea batatas & 125 & $31.99 \pm 0.56^{\mathbf{b}}$ & $36.09 \pm 0.50^{\mathbf{b}}$ & $36.43 \pm 0.81^{\mathbf{b}}$ \\
Ipomoea batatas & 250 & $32.34 \pm 0.34^{\mathbf{b}}$ & $37.44 \pm 0.29^{\mathbf{c}}$ & $37.78 \pm 0.20^{\mathbf{c}}$ \\
Ipomoea batatas & 500 & $32.05 \pm 0.21^{\mathbf{b}}$ & $37.45 \pm 0.33^{\mathbf{c}}$ & $37.48 \pm 0.29^{\mathbf{c}}$ \\
\hline
\end{tabular}

Values are mean \pm SEM with $p$-value $<0.05$. DW $=$ Distilled water.

\section{Peripheral blood smear}

From Figure 4, administration of graded dose of aqueous extracts induced normochromic and normocytic cells on damage red blood cells on day 14 showing effectiveness of the extract on red blood cells when compared across
$40 \mathrm{mg} / \mathrm{kg}$ phenylhydrazine hydrochloride and $5 \mathrm{mg} / \mathrm{kg}$ of ferrous (iii) hydroxide induced hypochromic macrocytes and normochromic and normocytic cells to $5 \mathrm{mg} / \mathrm{kg}$ of ferrous (iii) hydroxide group.

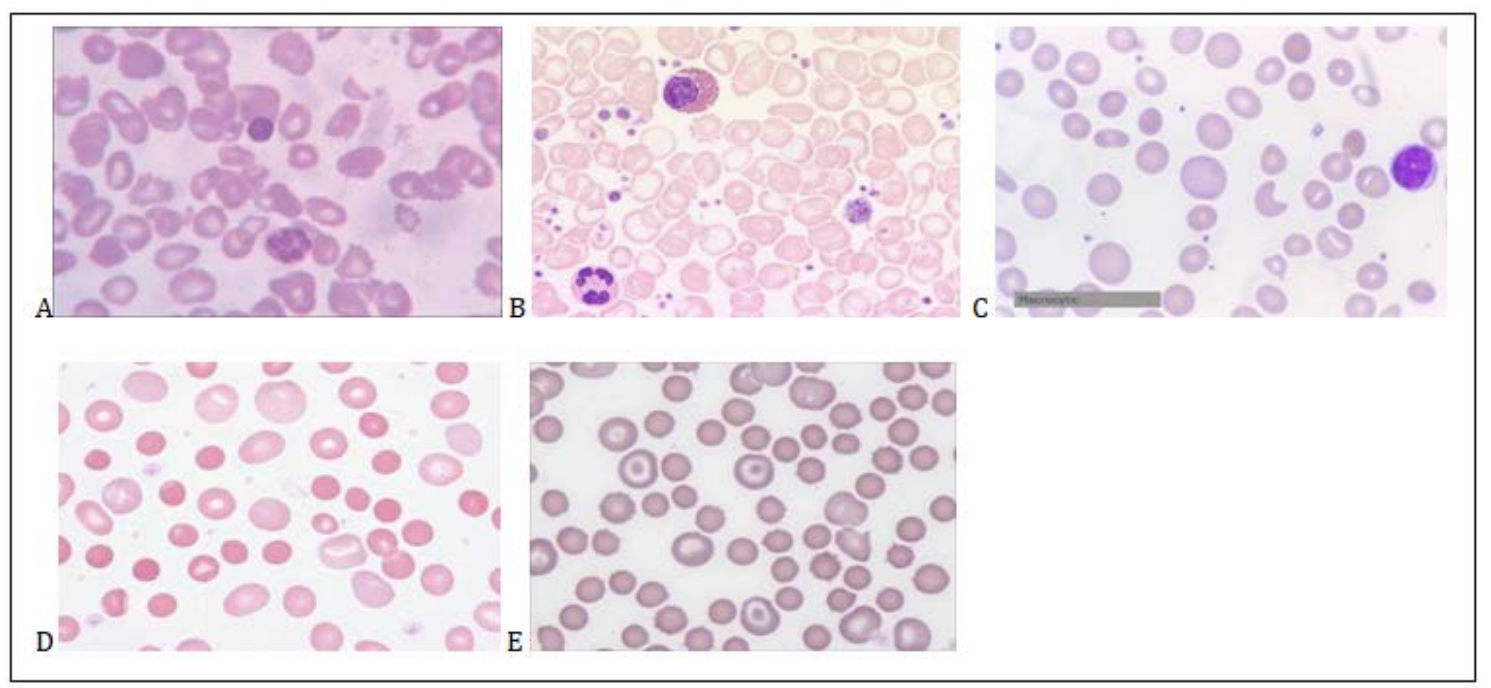

Figure 4. (A) Phenylhydrazine alone A, showed macrocytes. B, hypochromic macrocytes and C Platelet, (B) $5 \mathrm{mg} / \mathrm{kg}$ of ferrous (iii) - hydroxide A, showed normochromic and normocytic cell.B, multi-segmented neutrophil, (C) $125 \mathrm{mg} / \mathrm{kg}$ aqueous A, showed Normochromic macrocytic. B, helmet fragmented red cells C, normocytic red cell, (D) $250 \mathrm{mg} / \mathrm{kg}$ aqueous A, showed hypochromic macrocytic cells and partly normocytic cells and (E) $500 \mathrm{mg} / \mathrm{kg}$ aqueous plant extract A, showed normochromic macrocyte. B, burr cell and largely normocytic cells.

\section{Bone marrow}

From Figure 5, administration of graded doses of aqueous extract of I. batatas induced myelo-erythroid cells with mildly increased of about $60 \%$ for
$125 \mathrm{mg} / \mathrm{kg}, 65 \%$ for $250 \mathrm{mg} / \mathrm{kg}$ and $70 \%$ for $500 \mathrm{mg} / \mathrm{kg}$, when compared with Distilled water induced myelo-erythroid cells up to $75 \%$ which is normal, and less than $40 \%$ for $40 \mathrm{mg} / \mathrm{kg}$ phenyl hydrazine 
$\mathrm{HCl}$ group showing severe anemic condition in rats and $5 \mathrm{mg} / \mathrm{kg}$ of ferrous (iii) - hydroxide induced myelo- erythroid cells up to $70 \%$ at day 14 in anaemic treated rats.

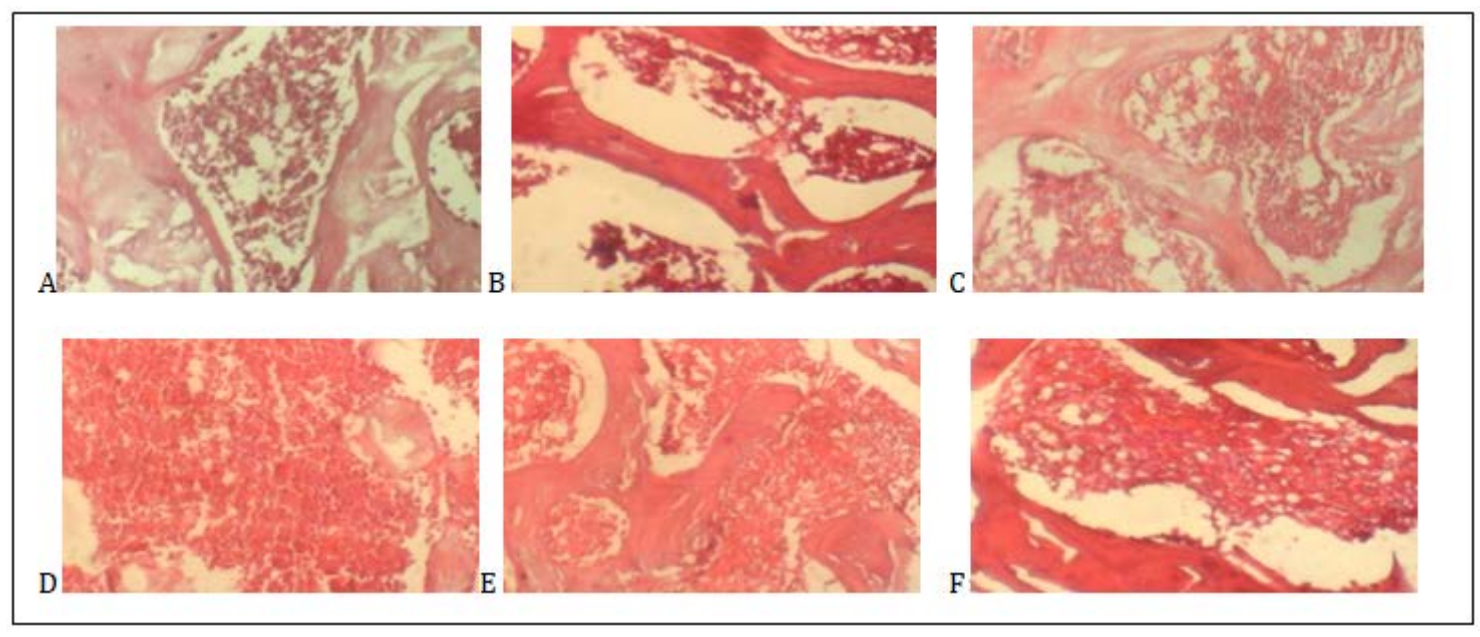

Figure 5. (A) Control Rat bone marrow composed of megakaryocyte, Bone and Myelo-Erythroid cells, fat vacuoles (B) Phenylhydrazine alone showed moderately decreased marrow, fat ratio, bone trabecula (C) $5 \mathrm{mg} / \mathrm{kg}$ of ferrous (iii) - hydroxide showed normal marrow, fat ratio (D) $125 \mathrm{mg} / \mathrm{kg}$ aqueous extract showed moderately increased marrow, fat ratio (E) $250 \mathrm{mg} / \mathrm{kg}$ aqueous extract showed moderately increased marrow, fat ratio and (F) $500 \mathrm{mg} / \mathrm{kg}$ aqueous extract showed moderately increased marrow, fat ratio at day 14 (H\&E x 100).

\section{Acute toxicological study}

Results from the observed acute toxicity studies revealed that aqueous extract was safe up to the highest dose of $500 \mathrm{mg} / \mathrm{kg}$. No harmful signs and symptoms or behavioural adverse effect was observed also, no mortality was recorded during the period of the study.

\section{Histopathological profile}

From Figure 6, administration of graded doses of aqueous extract of I. batatas induced moderate vascular dilation of the heart compared to graded doses of Control (distilled water), $40 \mathrm{mg} / \mathrm{kg}$ phenyl hydrazine hydrochloride and $5 \mathrm{mg} / \mathrm{kg}$ of ferrous (iii) hydroxide poly-maltose induced dilated coronary vessel and mild vascular congestion of the heart.
Administration of graded doses of aqueous extract of $I$. batatas induced normal follicular architecture on spleen when contrasted with graded doses of Control (distilled water), $40 \mathrm{mg} / \mathrm{kg}$ phenyl hydrazine hydrochloride and $5 \mathrm{mg} / \mathrm{kg}$ of ferrous (iii) - hydroxide polymaltose induced severe sinus dilation and mild follicular atrophy on spleen.

From Figure 7, administration of graded doses of aqueous extract of I. batatas induced normal follicular architecture on spleen when contrasted with graded doses of Control (distilled water), $40 \mathrm{mg} / \mathrm{kg}$ phenyl hydrazine hydrochloride and $5 \mathrm{mg} / \mathrm{kg}$ of ferrous (iii) - hydroxide poly-maltose induced severe sinus dilation and mild follicular atrophy on spleen. 


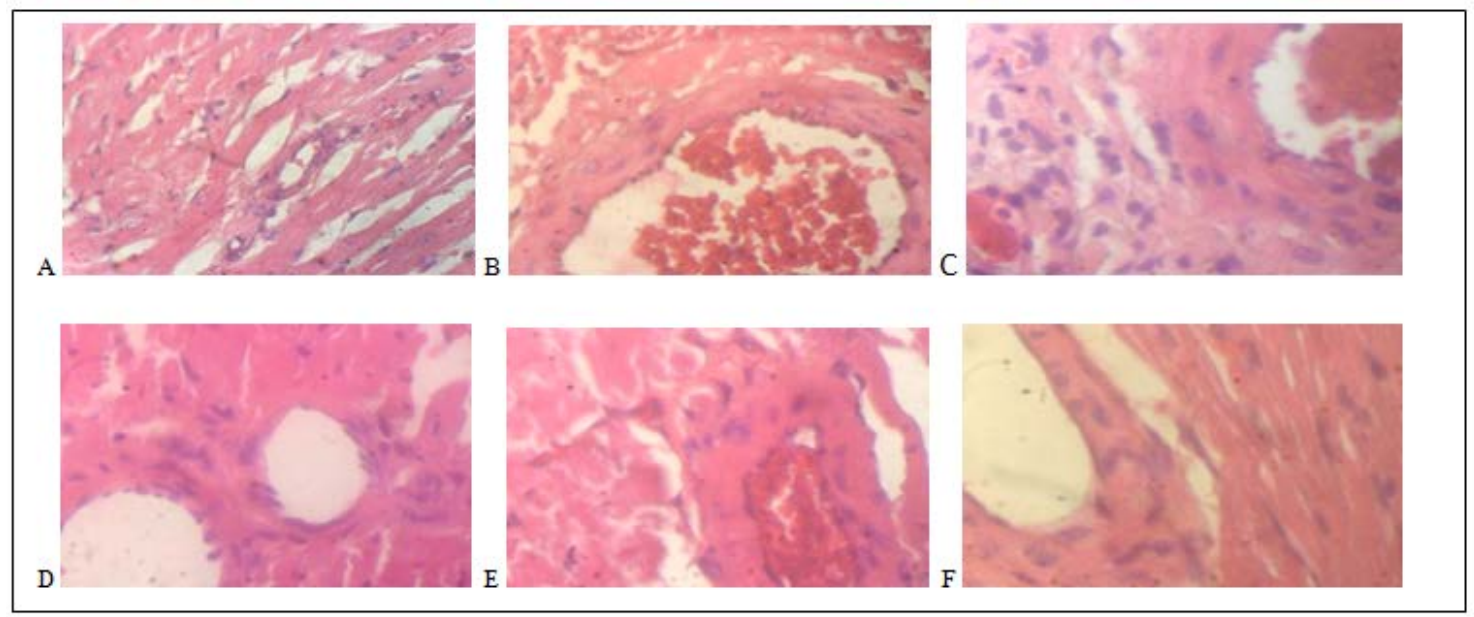

Figure 6. (A) Control Rat heart composed of; A, bundles of myocardiac fibres, B, coronary vessel and $C$, interstitial space, (B) Phenylhydrazine alone showed; A, dilated coronary vessel with B, mild vascular congestion, (C) $5 \mathrm{mg} / \mathrm{kg}$ of ferrous (iii) - hydroxide showing; A, dilated coronary vessel B, mild vascular congestion and $C$, heavy infiltrates of inflammatory cells, (D) $125 \mathrm{mg} / \mathrm{kg}$ aqueous extract showed A, moderate vascular dilation, (E) $250 \mathrm{mg} / \mathrm{kg}$ aqueous extract showed A, moderate vascular congestion, and (F) $500 \mathrm{mg} / \mathrm{kg}$ aqueous extract showed A, moderate vascular dilatation $(\mathrm{H} \& \mathrm{E})$ at day 14 .

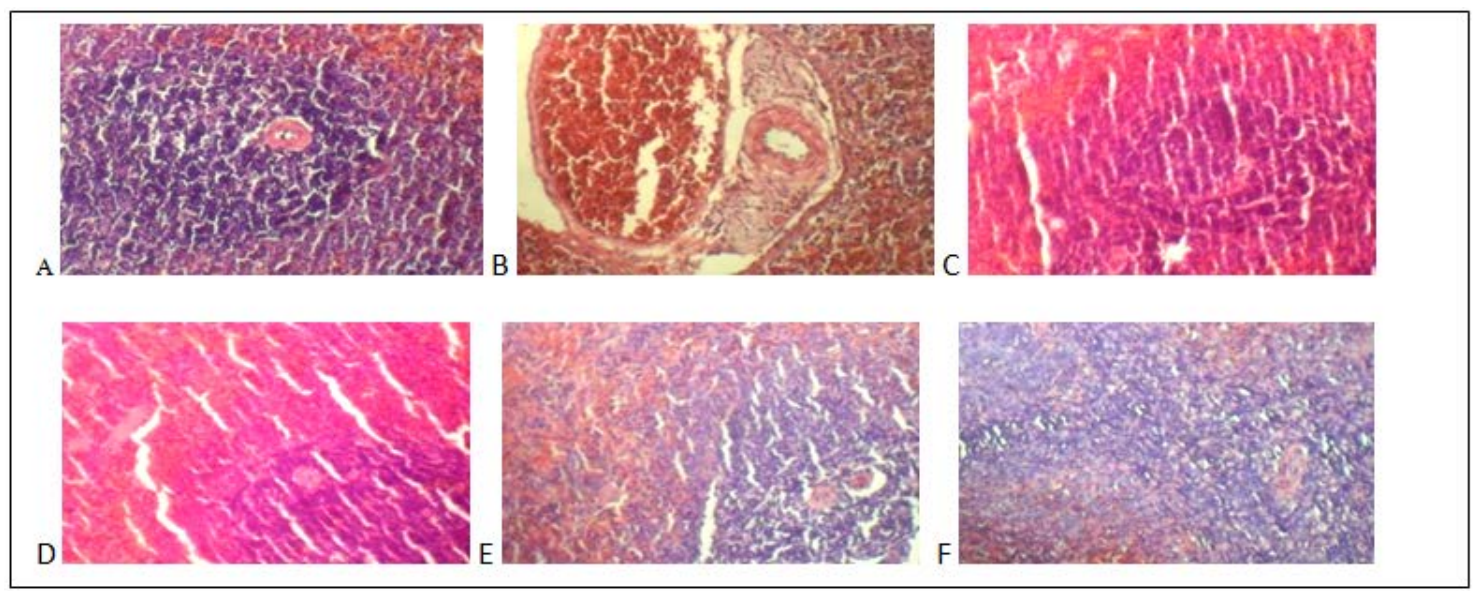

Figure 7. (A) Control Rat spleen composed of A, white pulp, B, red pulp and C, arteriole, (B) Phenylhydrazine alone showed A, severe sinus dilation and B, moderate follicular atrophy, (C) $5 \mathrm{mg} / \mathrm{kg}$ of ferrous (iii) - hydroxide poly-maltose showed A, mild follicular atrophy, (D) $125 \mathrm{mg} / \mathrm{kg}$ aqueous extract showed A, mild follicular atrophy, (E) $250 \mathrm{mg} / \mathrm{kg}$ aqueous extract showed A, normal follicular architecture and (F) $500 \mathrm{mg} / \mathrm{kg}$ aqueous extract showed A, normal follicular architecture (H\&E x 100) at day 14.

Administration of graded doses of aqueous extract of $I$. batatas induced mild vascular congestion and moderate Kupffer cell activation to the liver when compared with Control (distilled water), $40 \mathrm{mg} / \mathrm{kg}$ phenyl hydrazine hydrochloride and $5 \mathrm{mg} / \mathrm{kg}$ of ferrous (iii) hydroxide poly-maltose induced patchy vascular intimal ulceration and moderate vascular congestion in liver cells.

From Figure 8, administration of graded doses of aqueous extract of I. batatas induced mild vascular congestion and moderate Kupffer cell activation to the liver when compared with Control (distilled water), $40 \mathrm{mg} / \mathrm{kg}$ 
phenyl hydrazine hydrochloride and $5 \mathrm{mg} / \mathrm{kg}$ of ferrous (iii) - hydroxide polymaltose induced patchy vascular intimal ulceration and moderate vascular congestion in liver cells.

From Figure 9, administration of graded doses of aqueous extract of
I. batatas induced mild interstitial congestion in the kidney when compared with Control (distilled water), $40 \mathrm{mg} / \mathrm{kg}$ phenyl hydrazine hydrochloride and 5 $\mathrm{mg} / \mathrm{kg}$ of ferrous (iii) - hydroxide polymaltose induced interstitial space and focal vascular intimal to the kidney.

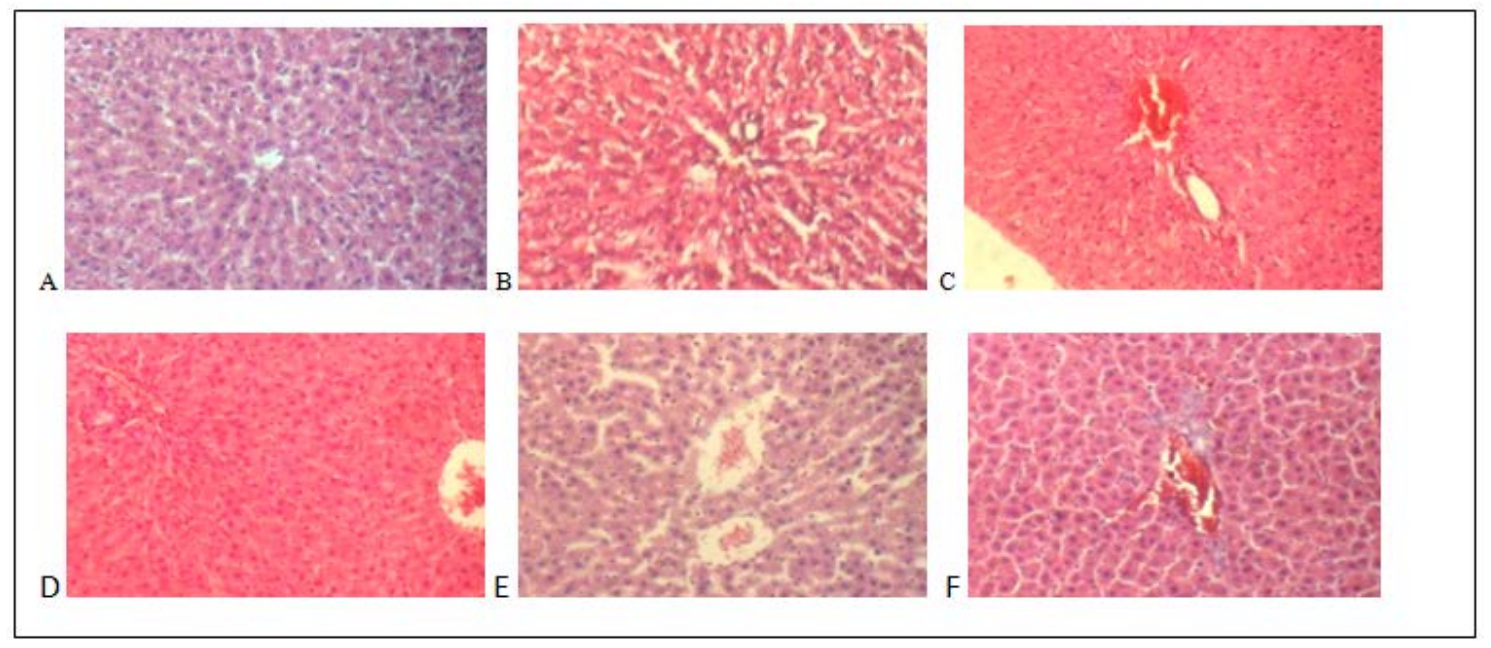

Figure 8. (A) Control Rat liver composed of central vein, hepatocytes and sinusoids (B) Rat liver treated with Phenylhydrazine alone showed patchy vascular intimal ulceration (C) Rat liver treated with $5 \mathrm{mg} / \mathrm{kg}$ of ferrous (iii) - hydroxide poly-maltose showed moderate vascular congestion (D) $125 \mathrm{mg} / \mathrm{kg}$ aqueous extract showed mild vascular congestion (E) $250 \mathrm{mg} / \mathrm{kg}$ aqueous extract showed mild vascular congestion and (F) $500 \mathrm{mg} / \mathrm{kg}$ aqueous extract showed mild vascular congestion and moderate Kupffer cell activation (H\&E x 100) of hepatocytes.

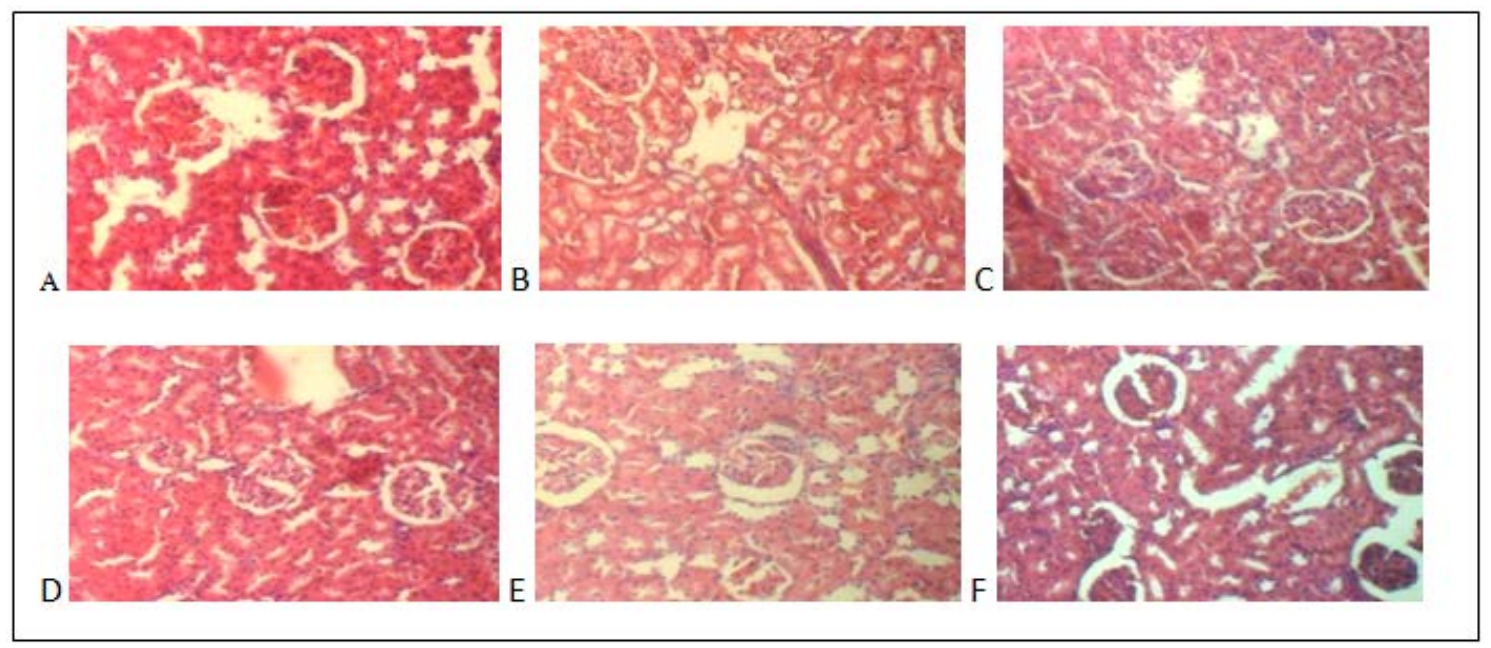

Figure 9. (A) Control Rat kidney composed of glomerulus, tubules and interstitial space (B) Phenylhydrazine alone showed focal vascular intimal erosion (C) $5 \mathrm{mg} / \mathrm{kg}$ of ferrous (iii) hydroxide poly-maltose showed mild interstitial congestion (D) $125 \mathrm{mg} / \mathrm{kg}$ aqueous extract showed mild interstitial congestion (E) $250 \mathrm{mg} / \mathrm{kg}$ aqueous extract showed mild interstitial congestion and (F) $500 \mathrm{mg} / \mathrm{kg}$ aqueous extract showed mild interstitial congestion (H\&E x 100) in kidney. 


\section{Discussion}

I. batatas showed its efficacy in radical-scavenging property useful in health-promoting activity. The plant extracts triggered radical scavenging activity against the produced oxygen derivatives in DPPH assay. Aqueous extract of $I$. batatas showed an increased in antioxidant activity when compared with the standard (ascorbic acids). The capability of the extract to inhibit oxidation from DPPH, signifies protons donor and scavenging effect for other stable radicals which is in line with the findings of Falodun and Irabor (2008), worked with methanolic extract of Calliandria surinamensis.

Proximate constituent of a particular plant is an absolute source of nutrients in that plant. The present of protein in the extract of I. batatas may be needed to stimulate necessary hormone required in facilitating bone marrow for blood cells production (AOAC, 2005).

Moisture and ash content are valuable in their stability, quality and purity of powered crude drug. The moisture content of $I$. batatas leaf was high when compared to Microdesmis keayana root as reported by Odesanmi et al. (2012).

Macronutrients display important activity in metabolism and enzymatic reaction when their functions are related to co-enzymes and co-factors. Magnesium, calcium, iron and phosphorus concentration in the leaf samples of $I$. batatas when compared with Microdesmis keayana root (Moswa et al., 2005). Magnesium, calcium, Iron and phosphorus is helpful for further development of bone marrow and to activate certain hormones (erythropoietin) for blood cells synthesis (Odesanmi et al., 2012; Moswa et al., 2005). High level of calcium and iron in the leaf of I. batatas was vital as it may aid protection of structural rigidity in the skeleton, thereby enhances red blood cells production (Moswa et al., 2005).
The present of zinc can be responsible for the stimulating effect of the plant in boosting the immune system (Sen et al., 2005).

Hemolytic anemia was induced with phenylhydrazine hydrochloride in Wistar rats and treated at 0,7 and 14 days using $10 \mathrm{mg} / \mathrm{kg}$ ferrous (iii) hydroxide and graded dose of $I$. batatas extract $(125,250$ and $500 \mathrm{mg} / \mathrm{kg})$. Aqueous extract of I. batatas leaf enhanced blood production in treated groups (Yamoto and Maede 2002; Yakubu et al., 2007). Results from the hematological index (Hgb, HCT, RBC, MCHC, MCV and MCH) in treated groups significantly increased hemoglobin, HCT and red blood cells $(14.40 \pm 0.92$, $46.13 \pm 0.08$ and $7.19 \pm 0.45)$ when compared with untreated group $(12.18 \pm 0.60,35.73 \pm 2.37$ and $4.33 \pm 0.19$ ) (Tables 1, 2 and 3). The Mean Corpuscular Volume (MCV) and Mean corpuscular hemoglobin concentration (MCHC) are constants for typical anemia. MCV decreased significantly in untreated group following the administration of phenylhydrazine that showed microcytosis. The decreased counteracted 14 days treated and untreated group. In addition, recompense was quicker with ferrous (iii) - hydroxide and I. batatas extract implying that diverse mechanisms are implicated in erythropoiesis. Recovery effect of blood cells probably could be as a result of erythropoiesis secreted from the kidney to regenerating blood cells in bone marrow. Hemoglobin (oxygen carrying capacity of the blood), MCV, MCH AND MCHC exhibited a significant increase in treated group, this finding agrees with the work of Cole (2006) and Adebayo et al. (2005) on ethanolic extract of Bougainvillea spectabilis (Yakubu et al., 2007; Yakubu and Afolayan, 2009) on aqueous extracts of Fadogia arggrestis stem and Bulbine natalensis stem. Extracts from I. batatas regenerates blood production with normal morphology when compared with 
untreated and reference drug groups in peripheral blood smear (Figure 4). Aqueous extract of $I$. batatas triggers myelo-erythroid cells at $60 \%, 65 \%$ and $70 \%$ across treated groups when compared with reference drug (75\%) having normal regenerated blood cells, and $40 \%$ in untreated group which is an indication of severe anaemia. These findings consent with earlier study of Sen et al. (2005) and Claro et al. (2006) on significant changes and increase in red blood cells percentage and morphology in myelo-erythroid cells (Figure 5).

No adverse toxicological effect of aqueous extract of $I$. batatas was observed with absent mortality (no mortality). It can be suggested that lethal dose $\left(L_{50}\right)$ of the extract is above $500 \mathrm{mg} / \mathrm{kg}$ since no death was recorded. This finding is in line with earlier study of Gasting et al. (2010) with no mortality from aqueous leaf extract of Alchornea cordifolia at $3,200 \mathrm{mg} / \mathrm{kg}$, methanolic and aqueous leaf extracts of Emilia coccinea at $8,000 \mathrm{mg} / \mathrm{kg}$ were administered (Idu et al., 2010).

Histological study of selected organs on day 14 following the administration of graded doses of the plant extracts showed vasoactive effects of the vessels (blood flow increase) when compared with untreated group (vascular hypertrophy in the kidney, heart, spleen and liver) which agrees with the findings of (Smith et al., 2002). The treated groups induced dilatation of coronary vessel with a mild vascular congestion as shown in Figure 6, compared with untreated group. The spleen showed normal follicular architecture in Figure 7 across graded doses. Figure 8 and Figure 9 showed a mild follicular activation and lymphocytosis of local immune system of normal liver and renal architecture. This finding is in line with previous study of (Smith et al., 2002) exposed to Cissus populnea.

\section{Conclusion}

It is relevant to consider that this research study validate the folklore use and showed essential preclinical information progressing to the development of anti-anemic herbal remedy in the country. Thereby the possibility of the isolation and feature of the bioactive component (s) accountable for the diverse pharmacological activities of the leaf extract of $I$. batatas should be determined in a bioactive guide to assay.

\section{Conflicts of interest}

Authors declare that they have no conflict of interests.

\section{References}

Adebayo, J. O.; Adesokan, A. A.; Olatunji, L. A.; Buoro, D. O.; Soladoye, A. O. Effect of ethanolic extract of Bougainvillea spectabilis leaves on haematological and serum lipid variables in rats. Biokemistri, v. 17, p. 45-70, 2005 . https://doi.org/10.4314/biokem. v17i1.32588

Antia, B. S.; Akpan, E. J.; Okon, P. A.; Umoren, I. U. Nutritive and anti-nutritive evaluation of sweet potatoes (Ipomoea batatas) leaves. Pakistan Journal of Nutrition, v. 5, no. 2, p. 166-168, 2006. https://doi.org/10.3923/pjn. 2006.166.168

AOAC - Association of Official Analytical Chemistry International. Official method of analysis. 18 ed. Maryland: AOAC, 2005.

Bratosin, D.; Mazurier, J.; Tissier, J. P.; Estaquier, J.; Huart, J. J.; Ameisen, J. C.; Aminoff, D.; Montreuil, J. Cellular and molecular mechanisms of senescent erythrocyte phagocytosis by macrophages: A review. Biochimie, v. 80, no. 2, p. 173-195, 1998. https://doi.org/10.1016/S03009084(98)80024-2

Claro, L. M.; Leonart, M. S.; Comar, S. R.; Nascimento, A. J. Effect of vitamin C and $\mathrm{E}$ on oxidative processes in human erythrocytes. Cell Biochemistry \& Function, v. 24, no 6, p.531-535, 2006. https://doi.org/ $10.1002 /$ cbf. 1255 
Cole, E. H. Veterinary clinical pathology. Philadelphia: W. B. Sander, 2006.

Dini, I.; Tenore, G. C.; Dini, A. Saponins in Ipomoea batatas tuber: Isolation, characterization, quantification and antioxidant properties. Food Chemistry, v. 113, p. 411-419, 2009. http://doi.org/ 10.1016/j.foodchem.2008.07.053

Drury, R. A. B.; Wallinton, E. A. Carletons histological technique. 16 . ed. London: Oxford University Press, 2003.

Falodun, A.; Irabor, E. I. Phytochemical, proximate, antioxidant and free radicals scavenging evaluation of Calliandria surinamensis. Acta Poloniae Pharmaceutica - Drug Research, v. 65, no. 5, p. 571-575, 2008.

Gasting, D.; Nkeugouapi, C. F. N.; Nkah, B. F. N.; Kuiate, J. R.; Tcheuanguep, F. M. Antibacterial activity, bioavailability and acute toxicity evaluation of the leaf extract of Alchornea cordifolia (Euphorbiaceae). International Journal of Pharmacology, v. 6 , p. 173-182, 2010. https://doi.org/ 10.3923/ijp.2010.173.182

Idu, M.; Erhabor, J. O.; Timothy, O.; Etatuvie, S. 0 . Phytochemical and acute toxicity studies of the aqueous extract and methanol extracts of Emilia coccinea (Sims.) G. Dm. Journal of Plant Development Sciences, v. 2, no. 3/4, p. 89-94, 2010.

Kaliora, A. C.; Dedoussis, G. V. Z.; Schmidt, H. Dietary antioxidants in preventing atherogenesis. Artherosclerosis, v. 187, no. 1 , p. 1-17, 2006. https://doi.org/ 10.1016/j.atherosclerosis.2005.11.001

Komolafe, O. I.; Awoniyi, A. O. The prevalence of microbial isolates associated with infertility in men attending clinic in OAUTHC, Ile-Ife. International Journal of Microbiology Research and Reviews, v. 1, no. 5, p. 88-91, 2013.

Konczak-Islam, I.; Yoshimoto, Y.; Hou, D.; Terahara, N.; Yamakawa, 0. Potential chemopreventive properties of anthocyaninrich aqueous extracts from in vitro produced tissue of sweetpotato (Ipomoea batatas L.). Journal of Agricultural Food Chemistry, v. 51, p. 5916-5922, 2003. https://doi.org/ 10.1021/jf030066o
Leong, L. P.; Shui, G. An investigation of antitoxic capacity of fruit in Singapore markets. Food Chemisty, v. 76, no. 1, p. 6975, 2002. https://doi.org/10.1016/S03088146(01)00251-5

Lessin, L. S.; Klug, P. P.; Jensen, W. N. Clinical implications of red cell shape. In: Stollerman, G. H. Advances in Internal Medicine. Chicago: Year Book Medical Publishers, 2006. v. 21. p. 451-499.

Lippi, G.; Schena, F.; Salvagno, G. L.; Aloe, R.; Banfi, G.; Guidi, G. C. Foot-strike haemolysis after a $60-\mathrm{km}$ ultramarathon. Blood Transfusion, v. 10, no. 3, p. 377-383, 2012. https://doi.org/10.2450/2012.0167-11

Moswa, J. L.; Kapanda, N.; Mungende, D. M.; Okitolonda, W.; Mayangi, M.; Mihigo, S. Plant as an important source of iron for the treatment of anaemia: Case of Justicia secunda. Proceedering of the XI NARECA, Madagascar, Antananarivo, p. 132-135, 2005.

Noda, N.; Horiuchi, V. The resin glycosides from the sweet potato (Ipomoea batatas L. LAM.). Chemical Pharmacology Bulletin, v. 56, no. 11, p. 1607-1610, 2008. https://doi.org/10.1248/cpb.56.1607

Odesanmi, O. S.; Ojokuku, S. A.; Apena, A.; Bikomo, O. E.; Lawal, R. A. Nutritional prospect of an aphrodisiac Microdesmis keayana. Journal of Medicinal Plants Research, v. 6, no. 7, p. 1187-1190, 2012.

Ozaki, S.; Oki, N.; Suzuki, S. Structural characterization and hypoglycemic effects of arabinogalactan-protein from the tuberous cortex of the white-skinned sweet potato (Ipomoea batatas L.). Journal on Agricultural Food Chemistry, v. 58, no. 22, p. 332-361, 2010. https://doi.org/ 10.1021/jf101283f

Rabah, I. O.; Hou, D. X.; Komine, S. I.; Fujii, M. Potential chemopreventive properties of extract from baked sweet potato (Ipomoea batatas Lam. Cv. Koganesengan). Journal of Agricultural Food Chemistry, v. 52, no. 23, p. 5916-5922, 2004. https://doi.org/ $10.1021 /$ jf049368w

Sen, G.; Mandal, S.; Saha, R. S.; Mukhopadhyay, S.; Biswas, T. Therapeutic use of quercetin in the control of infection and anaemia association with visceral 
leishmaniasis. Free Radical Biology and Medicine, v. 38, no. 9, p. 1257-1264, 2005. https://doi.org/10.1016/j.freeradbiomed.20 05.01 .014

Smith, A.; Edufunke, L. O.; Adeyemi, R. O.; Adeyemi, 0. A.; Lawson, A. A. Toxicity test of water homogenate of Cissus populnea stem in mice and its effect on weight of some organs, serum gonadotrophins, lipids and uric acids in male albino rats. Nigerian Quarterly Journal of Hospital Medicine, v. 10, p. 224-227, 2002. https://doi.org/10.4314/ nqjhm.v10i3.12475

Suda, I.; Oki, T.; Masuda, M.; Kobayashi, M.; Nishiba, Y.; Furuta, S. Physiological functionality of purple-freshed sweet potatoes containing anthocyanins and their utilization in food. Japan Agricultural Resource Quarter, v. 37, no. 3, p. 167-173, 2003. https://doi.org/10.6090/jarq.37.167

Telford, R. D.; Sly, G. J.; Hahn, A. G.; Cunningham, R. B.; Bryant, C.; Smith, J. A. Footstrike is the major cause of hemolysis during running. Journal on Applied Physiology, v. 94, no. 1, p. 38-42, 2003. https://doi.org/10.1152/japplphysiol.00631. 2001

Yakubu, M. T.; Afolayan, A. J. Effect of aqueous extract of Bulbine natalensis Baker stem on haematological and serum lipid profile of male wistar rats. Indian Journal of Experimental Biology, v. 47, no. 4, p. 283288, 2009.

Yakubu, M. T.; Akanji, M. A.; Oladiji, A. T. Hematological evaluation in male albino rats following chronic administration of aqueous extract of Fadogia argrestis stem. Pharmacognosy Magazine, v. 3, p. 34-47, 2007.

Yamoto, 0.; Maede, Y. Susceptibility to onioninduced hemolysis in dogs with hereditary high erythrocyte reduced glutathione and potassium concentrations. American Journal of Veterinary Research, v. 53, no. 1, p. 134-142, 2002.

License information: This is an open-access article distributed under the terms of the Creative Commons Attribution License, which permits unrestricted use, distribution, and reproduction in any medium, provided the original work is properly cited. 